$70 \mid$ InterAção

\title{
THE MIDDLE EAST AMID GLOBAL MULTIPOLARITY: THE EMERGENCE OF NEW ACTORS IN THE REGION INVOLVING THE BRICS COUNTRIES
}

Yasmin Mohammed

\begin{abstract}
Political instability and riots happening in many Arab countries coincided with the expansion of BRICS. These five countries are among the most powerful countries in the international arena and their opinions are of paramount importance since all members of the Security Council of the United Nations, China and Russia are permanent members and Brazil, India and Africa South are not permanent members, but are seeking permanent representation for greater influence in the world. The ongoing reorganization of the political landscape in the Middle East and North Africa opened new space for the BRICS to the international prestige on responding to this turmoil. The big changes are now being caused not by victories on the battlefield or new geopolitical alignments, but by a single factor in our modern world - rapid economic growth, which will profoundly impact the International Relations and International Security.
\end{abstract}

Keywords: BRICS. MENA. Arab Spring. Multilateralism.

\section{INTRODUCTION}

The BRICS is part of global geopolitics, with the goal of creating an identity that is to propose that "the world is multipolar and respect for the sovereignty of States is one of its essential characteristics". As regards the balance of power involves changing the agenda and decision-making of the international community in areas such as multilateral trade negotiations, the reform of the International Monetary Fund and the United Nations Security Council, and climate negotiations. The impact of the BRICS can be evaluated with the degree of consistency between them, as well as the ability to influence the international 
71 InterAção

system. Thus, this article aims to already assume that BRICS is a heterogeneous coalition of powers, often competing with each other, but they have a fundamental common goal which is to face the Western hegemonic claims that hurts the political sovereignty of states. So the BRICS - even democratic - diverge from Western countries liberal view this could be evidenced as opposed to the BRICS to any foreign intervention in countries affected by the Arab Spring.

In the context in which the global power structure has changed deteriorating American unipolarity, the impacts of this scenario were directly felt in the Middle East and North Africa (MENA $\left.{ }^{1}\right)$. With the withdrawal of the United States from Iraq, the protests in the Arab world become strong turning into a revolutionary wave in North Africa, the Middle East and the Gulf region, which represents the most significant transformation in the region since decolonization.

New powers in the MENA region are emerging with power and new leaders - such as Turkey, Egypt and Qatar - who seek not only an independent foreign policy, but also a strong role in the region. In a demonstration of a global structure change, there is a representation of when the former Egyptian president Mohamed Morsi $^{2}$ revealed the engagement of relations with Asia, choosing China as his first trip outside the Arab world. The rise of new powers like Brazil, Russia, India and China not only on the world stage, but also from years 2000, appear strongly in the Eastern and Southern Mediterranean region ${ }^{3}$.

Russia is one of the actors who returns in a stable manner and with a significant presence in the region since it had lost power in place after the

\footnotetext{
${ }^{1}$ MENA is the acronym used in academia to describe the region of the Middle East and North Africa.

2 Led Egypt since June 30, 2012 to July 3, 2013 of the Freedom and Justice Party founded by the Muslim Brotherhood. It was the first civilian president and first democratically elected Islamist activist in his country. After little more than a year in power, was ousted by a military coup supported by the people.
}

${ }^{3}$ Algeria, Egypt, Israel, Jordan, Lebanon, Libya, Morocco, Occupied Palestinian Territories, Syria and Tunisia. 
72 InterAção

disintegration of the former Soviet Union. With the Arab Spring, Russia fears Islamic radicalism strengthen in the eastern Mediterranean and the consequent flow of fundamentalist ideas to the area of fluency in the Commonwealth of Independent States.

China is growing power in the region as a strong backer of investments, while India is an aspiring power that has yet to overcome his "distant dilemma" toward the Mediterranean. Brazil is a newcomer to the region, but slowly makes its presence felt.

An overview of the interests of these actors in MENA is the energy issue that is of paramount need to maintain economic growth in particular countries like China and India. Besides the holder Persian Gulf oil region, the discovery of natural gas deposits in countries such as Syria, Lebanon and the Occupied Palestinian Territories (specifically the Gaza Strip) and Egypt makes these actors migrate to invest in those locations, as well Algeria and Libya, where there is extraction, exploration and transportation of trade in the oil and gas industry (HENDERSON, 2014).

Economic cooperation is also emerging to other fields. Russia, China and Brazil are seeking to increase trade with the region through various bilateral and multilateral platforms. In 2004, China established the cooperation China-Arab States Forum (CASCF) in order to discuss political, economic and security issues on the issues. The amount of bilateral trade between China and the Arab states grew rapidly from from US\$ 36.7 billion in 2004 to US\$ 200 billion in 2011 (JIECHI, 2012). Russia created intergovernmental bilateral committees for economic, commercial and scientific cooperation, as well as create a RussianArab Business Council to boost economic and commercial interaction thus grew from \$ 2.45 billion in 2000 to \$ 10.83 billion dollars in 2010 (SMITH, 2002). In relation to Brazil, platform for the promotion of relations with the region is 
$73 \mid$ InterAção

through diplomatic, commercial, scientific and cultural sectors established since 2005. Within Mercosur, Free Trade Agreements with Palestine, Israel and Egypt, and preferably with Syria and Jordan. Despite the efforts of the Arab countries, Brazil still accounts for a small portion of Brazilian exports (BAKHTIN et al, 2013).

India establishes bilateral relations with countries in the region, unlike other powers acting regional strategy. India, however, has established a robust trade relations with Israel since the 1990s, and China, Russia and Brazil also intensified its relations with the Jewish state. The interest to the Israeli military technology has made these countries hone relations with Israel. Moreover, it is a matter of prestige to be accepted as the main actor for mediating conflict in the region - the Arab-Israeli conflict - as well as the Israeli-Iranian conflict. Thus, all four countries have highlighted their economic relations with Israel from the peace process, concomitantly, continue to be critical to Israel on issues like construction of illegal settlements in Palestinian territories, and further support the self-determination of the Palestinians in search of building Sovereign of the State, as became clear when the BRICS voted in favor of joining the Palestine Liberation Organization to the United Nations Educational, Scientific and Cultural Organization and the category of the UN Observer State. About the Iran, the BRICS shares the concern of the West over Iran's nuclear program, but believe that negotiations are the only viable way for a solution (BAKHTIN et al, 2013).

The BRICS states have recognized that political unrest in the Middle East is the potential to transform the region. In reference to the Arab uprisings, the BRICS widely share similar interests to the West, how to contain the Syrian conflict to not generalize across the region and prevent the radicalization of the Mediterranean. In the North African states of Spring - Egypt, Tunisia and Libya 
$74 \mid$ InterAção

- has great potential for cooperation with the West and the BRICS aiming to support the process of sustainable transition there (CHELLANEY, 2011).

The multilateral global forums, such as the G20 or local variants, can serve as model version for a Mediterranean Union to coordinate effective technical assistance for economy through the establishment of a common financial framework. In fact, the need for regional cooperation and the creation of a forum linking the Mediterranean with the West and the BRICS may provide greater relationships on economic and security issues. The crisis in Syria is the best example of the issue of creating a forum. The cooperation between the West and the BRICS - specifically Russia - would be crucial to end the civil war in Syria step because what happens in Syria is a global competition at regional level, between West competition along with Russia and the region Gulf with Iran, as well as local disputes inside Syria, which keeps this violent conflict running. Therefore, the West and Russia must find a way to press the warring parties to negotiate and ensure that regional and local actors comply with the agreement.

\section{THE BRICS AND THE ARAB SPRING}

The BRICS, a product of globalization and the Iraq war, are heirs of the globalized economy and unconditional supporters of economic liberalization process, condemning the economic protectionism of certain countries, especially since the 2008 financial crisis The fact that the concept of BRICS was created by an investment bank, while the concept of the Third World was formed by a demographer (Alfred Sauvy) reveals how economic globalization has come to shape geopolitical representations. The geopolitical world has gone into a new phase after September 11 and the Iraq War. In this context, the political 
75 InterAção

sovereignty of the Iraqi state was challenged on the basis of the Bush Doctrine of preventive war, which caused profound negative issues in the international arena. With the argument that the United States would not hesitate to use force against any country that might thwart their interests, the BRICS themselves were indirectly exposed to this threat. Brazilians, for example, had expressed concern about Plan Colombia of the United States in 2009 and once again raised the question of the purpose of American air bases in the Amazon during a visit to Brasilia in 2011 by President Obama. In addition, Brazilian diplomats constantly refer to the case of Iraq, especially to justify the refusal of his country to seek sanctions against Iran. For Brazil, as for other emerging countries, the application of sanctions is a prelude to the war (LAIDI, 2011).

The policy crystallization that led the emergence of BRICS occurred in 2003, it was chronologically preceded the creation of the IBAS (India, Brazil, South Africa), the three countries are portrayed as multi-ethnic, multicultural and democratic. The BRICS obviously could not claim to share a common orientation with respect to the nature of the Russian and Chinese regimes. They were not bound by democracy, but by a desire to democratize the international system. In any case, the economic and financial crisis in 2008-2009 said the role played by emerging countries in the international system, because without them the recession would have been deeper (LAIDI, 2011).

\section{RUSSIA: PRESENCE IN THE MIDDLE EAST AND INTERESTS}

Russia does not present itself as a new actor in MENA, as the historical link with the region is something noticeable until today. The current Russian interests in the Mediterranean are formed by bilateral and multilateral relations. 
76 InterAção

The foreign policy of the Soviet Union (USSR) period in relation to African and Arab countries was largely based on Soviet support for decolonization, plus the help of large infrastructural projects for local exemplified by the construction of the Aswan Dam (Egypt), metallurgical plant El-Hadjar, dams and Beni Zid Tilezdit in Algeria, and in many other countries such as Morocco, Tunisia and Libya. Since the period of the USSR had a large volume of arms exports to the Arab countries, like Libya that was the largest importer, nonetheless with the disintegration of the USSR resulted in discontinuation of connection with the Arab world, which is only resumed from 90s when Russia begins to operate in the region (GUSAROV, 1997).

In the Mediterranean, Russian policy is directed to energy, irrigation, infrastructure and armaments industries. The confessional composition of the Russian population and the large number of Russian descent who live in the region provide a strong impetus for Russia to develop cultural and religious relations with many states as sanctuaries orthodox Christians, Jews and Muslims. The Russian presence in the region is currently stable, especially after the official visit of President Vladimir Putin to strategic countries in the region such as Egypt, the Occupied Palestinian Territories, Israel, Algeria and Morocco between 2005 and 2006 (PROZOROVA, 2009). One priority is to manage their multidimensional security issues, including regional conflicts, terrorism and energy, as well as environmental issues to work together with the countries of the region through the United Nations and other specialized organizations for regional crisis prevention and resolution of conflicts. An analysis of the geopolitical and geo-economic situation both in the Mediterranean, as in Russia reveals that the following factors determine Russian interests in the region: a strategic presence in the region; the proximity of the eastern Mediterranean with the borders of the countries of the Commonwealth of Independent States; the 
77 InterAção

possible entry of terrorists and fundamentalists in the northern Caucasus region and economic and trade cooperation (BAKHTIN, 2013).

The factor of security, Russia is deeply concerned about the spread of terrorism and Islamic fundamentalism in the Middle East result of the Arab Spring to the Caucasus region. The wahabistas ${ }^{4}$ are infiltrating in some places in Russia promoting moderate Islamic circles in the Russian Muslim region, mainly in Tatarstan. Moreover, Russia is concerned about stabilizing Afghanistan because there is an increase of opium production in the country that has been transported to Russia becoming a national security issue by increasing consumption of heroin (BURLINOVA, 2011). Two other issues to be addressed in the region is the implication associated with the Iranian nuclear program and the Israeli-Palestinian conflict. The possible production of nuclear weapons by Iran is absolutely undesirable for the Russians in that it can ignite weapons of mass destruction in a region very close to the borders of the CIS. However, politically Moscow to a military solution is unacceptable because it would trigger a major war creating more local instability, and uses political solution through negotiations with Iran and not coercive measures. Concomitant to this, Russia and Iran are interested in developing bilateral cooperation for purely economic reasons. Russia has a record of success in cooperation with Iran, including the construction of the Bushehr nuclear power plant for peaceful use of atomic energy released in 2011. another crucial approach to the region is the IsraeliPalestinian conflict, which Russia traditionally has had significant influence at different points on different issues take sides by Israel or Palestine becoming a

\footnotetext{
${ }^{4}$ Wahhabism is a religious Muslim ultra-conservator movement that had its inception in central Arabia in the mid eighteenth century and originally created by Muhammad bin Abd al Wahhab. The political and cultural environment of contemporary Saudi Arabia is influenced by this movement from the mid-eighteenth century. It also has strong influence in Kuwait and Qatar.
} 
78 InterAção

sponsor internationally recognized in the peace process in the Middle East while maintaining a position of neutrality (BAKHTIN et al, 2013).

Regarding the case of Syria, we have the political relationship by being an ally of Syria confidence to Moscow, beyond the military interest, where the Syrian port of Tartus is very important for the Russian military presence in the Middle East. Thus, the current economic interest is the sector of weapons, Syria is a major market for Russian weapons, also for investments in infrastructure projects. The humanitarian importance is taken into consideration, since 30000 Russian citizens living in Syria (INYUTIN, 2012).

In the economic aspect, according to the statistics of $\mathrm{UNCTAD}^{5}$ the value of goods in the Russian-Mediterranean trade flows (exports and imports) in 2000 totaled $\$ 2.45$ billion with Israel (which represents $40 \%$ of total trade with the region) and the Morocco (13\%). By 2011, Egypt and Morocco grow the volume of trade with Russia reaching $23 \%$ of the volume, in addition to Tunisia that reaches $11 \%$ of trading volume. However, the participation of the Mediterranean in the Russian trade flow with the outside is still insignificant $(0.04 \%$ in $2000,0.06 \%$ in 2011). Nevertheless, the growing trade between both four times as illustrative chart (see graphic 1), which shows the restoration of Russia in the region and the Arab Spring could hurt Russian achievements in the MENA. In short, by 2010, Russia restored economic or political ties with key stakeholders in the region: Iran, Syria, Saudi Arabia, Qatar, Iraq, Afghanistan, Israel, Fatah, Hamas and Hezbollah (KATZ, 2012).

${ }^{5}$ United Nations Conference on Trade and Development. 
Graph 1: Total volume of trade between Russia and the Eastern Mediterranean

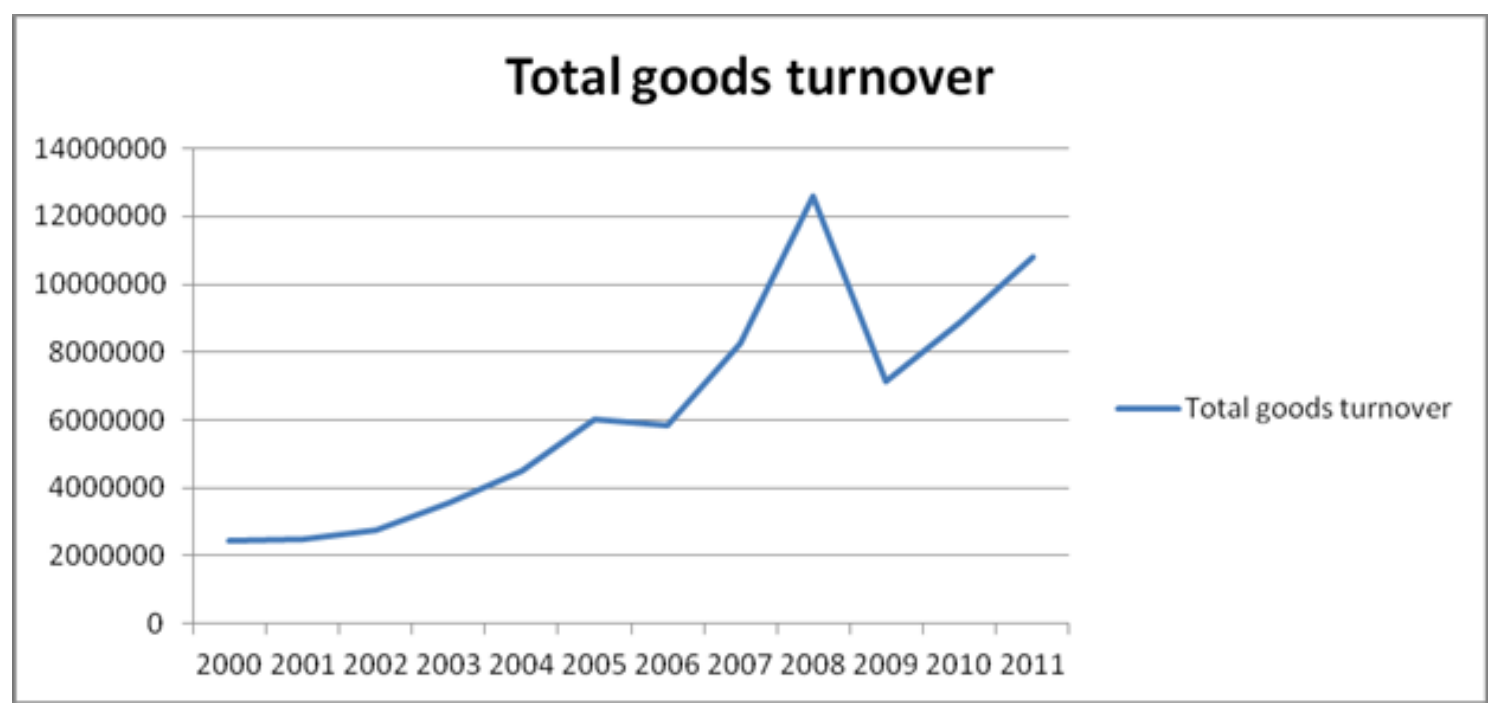

Source: UNCTAD, 2012.

\section{INDIA: OVERCOMING REMOTENESS IN RELATION TO THE MIDDLE EAST}

Although recognized as the fourth largest economy in the world, India is not able to use their economic influence to achieve their political interests abroad. The Persian Gulf provides $60 \%$ of the oil imported by India and accounts for $25 \%$ of total Indian exports. The main political interests are concentrated in Israel, Egypt, and to a lesser extent Syria, remain bilateral relations, it demonstrates the 
80 InterAção

tune of India's foreign policy that lacks the regional approach. India has improved its bilateral relations with Israel increase the flow of trade which is currently about $\$ 6.6$ billion (FOREIGN TRADE OF INDIA, 2014).

Regarding the Arab Spring, India was not positioned directly advocates not only outside intervention. In the Persian Gulf region important for India in the economic, social and energy sectors, the Indian policy remained neutral because it could endanger their five million expatriate workers who contribute significantly in annual shipments nearly \$ 55 billion during 2010-2011 (MINISTRY OF OVERSEAS INDIAN AFFAIRS, 2012).

While Russia and China are established powers in the Mediterranean, India is still aspiring to that power, since it was unable to create opportunities in the region due to the nuclear deal with the USA signed in 2005, which limited access to other sites did not maintain strong relations with the Americans. The use of regional consensus is an interim strategy to India gain greater influence in the region, because in terms of the BRICS, Indian Country faces competition and rivalry of China and Russia over energy security and no external intervention (KUMARASWAMY, 2007).

\section{BRAZIL: NEW ACTOR IN THE MEDITERRANEAN}

Relations between Brazil and the Arab World during the Post-Cold War has been through three distinct phases: the first phase consisted of a reduction in trade flows and policy between both sides; the second phase at the beginning of the presidential term Cardoso was characterized by a reheating of trade relations between Brazil and the Arab countries without political approach and the third 
81 InterAção

phase with the Lula government evidenced strengthening political and trade relations (MESSARI, 2006).

From the twentieth century during the second phase of the government of Fernando Henrique Cardoso has begun the relations between Brazil and the countries of MENA, especially in the commercial sector. With government ownership by Luís Inácio Lula da Silva in 2003 what had begun as pragmatism in foreign affairs and trade becomes a systematic effort to increase the political and diplomatic ties. Thus, the Summit of South American and Arab Countries (ASPA) was created in 2003 to stimulate several sectors.

Maintained contacts with foreign leaders has allowed cooperation not only in economic and political fields, but joint efforts in the fight against desertification in Brazil and the Arab countries. Efforts ongoing to establish cooperation included the increase in the number of Brazilian embassies in the region that focuses on 17 of the 22 countries of the Arab League. Today, the only Arab countries that do not have Brazilian embassies are Yemen, Bahrain, Djibouti, Comoros and Somalia. In addition, Brazil is one of only four observer states of the Arab League - along with Eritrea, Venezuela and India - a status that gives him the right to give his opinion and advice, but denies the right to vote. Another point that Brazil presents itself as a key actor in the region of the countries of the Maghreb and West Africa is on food safety, Morocco is trying to add the Brazil in discussions on Agricultural Development and Cooperation to Combat Desertification (ANBA, 2006 ).

Starts in 2010 when the Arab Spring, Dilma Rousseff takes possession of the Brazilian government, the Ministry of Foreign Affairs was caught surprised about it and took time to issue statements condemning the excessive use of force against protesters. In the case of Syria and Libya, the Foreign Ministry faced the dilemma of how to defend the principles of national sovereignty and human 
82 InterAção

rights of two nations whose governments maintained a bond with Brazil. Thus, the foreign policy of the Dilma government is founded on traditional defense of national sovereignty and non-intervention in foreign affairs. The issue in Libya, Lula had maintained good bilateral relations with Colonel Muammar Gaddafi in investment and trade, besides Petrobras start exploring oil and gas in Libya in 2005, along with the Lybian National Oil Corporation. During the crisis, Brazil supported the measures of Resolution 1970 of the Security Council of the United Nations, adopted in February 2011 (arms embargo, travel bans abroad, the freezing of bank accounts of Muammar Gaddafi, the presentation of the case the International Criminal Court and the decision to suspend Libya from the Human Rights Council of the United Nations). However, on March 17, Brazil, Germany, China, India and Russia abstained from UNSC Resolution 1973 that established a no-fly zone in Libya (KALOUT, 2012).

Brazil's role in searching through the creation of ASPA summit, as well as through visits and exchanges intensified growing trade and economic exchanges more active role in the Mediterranean region is shaping its international image addressing important geostrategic issues as the conflict over Iran's nuclear program and the Israeli-Palestinian conflict. The Arab Spring has not changed the foreign policy approach to the region, but was perceived by Brazil that views its democratic transition of the 1980s can serve as a model for the Arab countries, but does not intend to enforce it. Moreover, the Foreign Ministry has not issued official statement regarding the rise of political Islamism, exemplified by the normal relations that the country has with Iran, Israel as a state semi-religious and feudal monarchies like Saudi Arabia and Qatar. Therefore, we emphasize the importance of commercial, political and strategic growth in the south and east of the Mediterranean, there is a great field to be exploited, to diversify the exports to these countries, it has a large robust consumer market. 


\section{CHINA: THE SEARCH FOR ENERGY RESOURCES AND MARKETS}

The MENA countries are becoming energy providers to China in the region Algeria stands as the largest supplier. China's interest in this area can be explained by the proximity of this region to Europe, and present a market of 800 million consumers. According to the Center for Investment Projects for the Mediterranean (MIPO), China between 2003 and 2006 invested 1.45 billion euros distributed mainly between Egypt, Algeria and Syria (PECORARO, 2010).

The Middle East has become the seventh largest trading partner of China in bilateral trade volume reaching $\$ 268.9$ billion in 2011, and the annual growth rate of $36.5 \%$. The Chinese expansionism in the South and East of the Mediterranean is due to two main reasons: China faces industrial overproduction and market saturation in various sectors, such as textiles and electronics and we must expand markets to maintain sustainable economic growth and China need of energy resources as well as timber, fish and natural gas to maintain its economic expansion (BAKHTIN et al, 2013).

China expanded its presence in the Middle East and North Africa market sectors in which European and American industries did not invest, so tends to replace the Euro-American hegemony and establish partnerships to contribute to the development of the area. In addition, the main challenge to the growth of the Mediterranean region is the balance between environmental sustainability and social transformation, as the Chinese presence there certainly entail the environmental disturbances by strong exploitation of energy resources. China invests in infrastructure and technological capability that comes with the shift of production units for some MENA countries contributing to the greater supply of 
$84 \mid$ InterAção

jobs and purchasing power. With the exception of Algeria, which is an exporter of oil, the other Mediterranean countries need to boost unexplored sectors like petrochemical, agricultural and manufactured products, where the region has comparative advantages, corresponding to demand in the global market to specialize in renewable energy, which provides the partnership with China in this sector.

The Chinese position in relation to the Arab Spring is to maintain the principle of non-interference in other countries, thus opposing the initiative of some states to intervene in Arab countries. China's position was understood and appreciated by countries and peoples of the region. Therefore, China's relations with the Arab countries were not affected, and the trade remained at a high level in important geo-strategic countries such as Egypt, as well as other key countries in the region who have been affected by the Arab Spring in varying degrees. The Chinese Prime Minister, Wen Jiabap and Vice President Xi Jinping made successful visits to Saudi Arabia, Qatar, United Arab Emirates, among others. In addition, on May 31, 2012, CASCF (Conference of the China-Arab States Cooperation) held its Fifth Ministerial Conference in Tunisia. During the conference, Yang Jiechi, Chinese Minister of Foreign Affairs had in-depth conversations with Arab countries on how to increase the strategic cooperation and promote common development (XIAODONG, 2012).

Finally, good relations also remain in terms of the contact between people and populations. Currently, there are about 2000 people who commute between China and the Arab countries, almost 8000 students from Arab countries are studying in China and about 500 Chinese doctors who offer their services in different Arab countries. However, there is a shoulder on issues that guide the regional situation and that can be challenges or opportunities for China as its 
$85 \mid$ InterAção

positioning - Libya, Syria, Egypt and Palestine-Israel - cases that are still evolving and still not be solved.

\section{CONCLUSION}

The changes that witness in the Mediterranean are fruits of the new system of international relations created after the Second World War. New actors are added to the analysis beyond the classical world powers. The challenges experienced by the MENA countries are often similar to those of the West, so it is crucial to cooperation in dealing with security issues, especially after the Arab Spring. Thus, in addition to cooperation in the security area, we have other points to be expanded as energy sources, economic development, reducing social inequality, which was the main reason for the revolutions in Tunisia and Egypt, where the population dissatisfied living conditions raised towards improvements.

Sovereignty is one of the main pillars advocated by BRICS at odds with the West, where the UN vote against any form of intervention sovereignty of repressive states, as mentioned above on the Libyan case. On Iran and Syria, the group remained firm in his non-interventionist stance, preferring that the situations are resolved without military intervention by the UN. However, the resolution supporting the Arab League plan for the removal of Syrian President 
86 | InterAção

Bashar al-Assad, India, Brazil and South Africa voted in favor of the resolution, while Russia and China voted against.

It is worth considering whether the BRICS will act in the Mediterranean as a cohesive group or markets and energy sources compete with each other. As boundaries are being redrawn in the Middle East it is known that the region will not be the same. Russia returns to the scene with strong military interest. China in search of new markets and energy resources. India does not have an activism in the region, but it denotes strong commercial interest. Brazil enters the region with an active economic and political diplomacy, especially in the agribusiness sector, which according to the Arab Brazilian Chamber of Commerce, the company will MARFRIG to build a factory in Saudi Arabia over the next five years, with the countries of MENA are among the 20 largest consumers of meat and poultry from Brazilian industries. So there is a need for closer cooperation and coordination of positions on international issues of importance, keeping in mind the broader interests.

\section{REFERENCES}

ANBA. Marfrig Planeja Fábrica No Oriente Médio. Brasil, 2014. Available in: < www.anba.com.br/noticia_impressao.kmf?cod=21863830\&pdf $=1>$. Accessed: 20 jun. 2014.

BAKHTIN, V. et al. The Mediterranean Region in a Multipolar World Evolving Relations with Russia, China, India and Brazil. Washington: The German Marshall Fund of the United States, 2013. p.1-43.

BURLINOVA, N. “War in Afghanistan (2001-2011): Overview and Perspectives" (in Russian),Perspectives, July 1, 2011. Available in: < http:/ / www.perspektivy.info/oykumena/amerika/vojna_v_afganistane_2001_2011_ gg_obzor_i_perspektivy_2011-07-01.htm>. Accessed: 1 jun. de 2014. 
$87 \mid$ InterAção

CHELLANEY, B. BRICS and the New Arab Revolutions. AMEC, 2011. Available in: <http://www.amec.org.za/articles-presentations/middle-eastgeneral/125-brics-and-the-new-arab-revolutions>. Accessed: 15 maio de 2014

DIRECTOR GENERAL OF FOREIGN TRADE OF INDIA STATISTICS, 2014. Available in: <http:/ / commerce.nic.in/eidb/default.asp>. Accessed: 5 jun. de 2014.

GUSAROV Vladilen I., Post-Soviet Russia's Economic Ties with the Arab World (in Russian), Moscow, Institute for Oriental Studies of the Russian Academy of Sciences/Institute for Israeli and Middle Eastern Studies, 1997, pp. 34-35. Available in: <

http:// www.iimes.ru/rus/book/1997/sbor/r97sbor_1.zip>. Accessed: 2 jun. de 2014.

HENDERSON, S. Natural Gas in the Palestinian Authority. GMF-USA, 2014. Available in: $<$ http://www.gmfus.org/archives/natural-gas-in-thepalestinian-authority / > . Accessed: 3 jun. de 2014.

INYUTIN, V. "Russia Abandons Its Citizens Amid Battle Action in Syria" (in Russian), NR2 New Russia, August 2, 2012. Available in:< http:// www.nr2.ru/moskow/397667.html>. Accessed: 2 jun. de 2014.

JIECHI, Y. Boosting Arab-China strategic cooperation. Arab News, 2012. Available in: <http:/ / www.arabnews.com/boosting-arab-china-strategiccooperation>. Accessed: 3 jun. De 2014.

KATZ, M. “Moscow and the Middle East: Repeat Performance?,” Russia in Global Affairs, Vol. 10, No. 4, July-September 2012,. Available in: < http:/ / eng.globalaffairs.ru/number/Moscow-and the-Middle-East-RepeatPerformance-15690 > . Accessed: 5 jun. 2014.

KALOUT, Hussein, A. “Oriente Médio: Itamaraty sem estratégia," Folha de São Paulo, July 23, 2012. Available in:< http:/ / www1.folha.uol.com.br/fsp/opiniao/56029-oriente-medio-itamaratysemestrategia.shtml>. Accessed: 11 jun de 2014.

KHORRAMI, N. Russia's Middle East ambitions. Al Jazeera, 2011. Available in: $<$

http:// www.aljazeera.com/indepth/opinion/2011/08/2011828943035319.html $>$. Accessed: 10 jun. de 2014.

LAIDI, Z. The BRICS against the West?. CERI Strategy Papers, 2011. Available in: 
88 InterAção

<http://www.sciencespo.fr/ceri/sites/sciencespo.fr.ceri/files/n11_112011.pdf $>$. Accessed: 20 maio de 2014.

MESSARI, Nizar. O Brasil e o mundo árabe. In: OLIVEIRA, Henrique Altemani \& LESSA, Antônio Carlos (orgs.). Relações internacionais do Brasil: temas e agendas. São Paulo: Saraiva, 1, 2006, p.299-320

MINISTRY OF OVERSEAS INDIAN AFFAIRS, Annual Report 2011-12, p. 36. Available in: < http:/ / moia.gov.in/writereaddata/pdf/annual_report_20112012.pdf>. Accessed: 7 jun. de 2014.

PECORARO, E. “China's strategy in North Africa and future economic challenges for the Mediterranean region".EUGOV Working Paper, No. 25, November 2010. Bellaterra (Barcelona): Institut Universitari d'Estudis Europeus

PROZOROVA, Galina K. Russia and the Countries of the Near East, Middle East and North Africa. Problems and Prospects of Cooperation. A collection of articles (in Russian), Moscow, East- West, 2009, p. 54.

SANTOS, A. "Exports to the Arabs grow by 20\%," ANBA. Brazil-Arab News Agency, January 31, 2012. Available in:

http:// www2.anba.com.br/noticia_corrente.kmf?cod=13028777. Accessed: 10 jun. de 2014.

SMITH, M. Russia \& The Middle East, Conflict Studies Research Centre, Setembro, 2002.

XIAODONG, C. "China's Relations with the Arab Countries," Aljazeera, May 30, 2012. Available in: $<$

http://news.bandao.cn/news_html/201205/20120531/

news_20120531_1917839.shtml>. Accessed: 20 jun. de 2014. 